\title{
The Crisis of Historical Materialism and \\ Phenomenology
}

\author{
Raymond A. Morrow \\ University of Alberta
}

The articles which follow ostensibly focus on the theoretical reflections and personal experiences of a prolific and influential radical critic of American education, Michael Apple. Yet they also provide eloquent witness to the continuing agonies of the American Left, as well as sketching an agenda of issues which touch on the relationship between phenomenology and power in the last decade of our century.

The article "Ideology, Equality, and the New Right" outlines in an unflinching, candid manner a theoretical interpretation of the failure of the liberal (or social democratic) accord of modern American politics, the inadequate responses of the New Left, and the subsequent conservative restoration (Reaganism) along lines first developed by Hall and others to explain the authoritarian populism underlying Thatcherism (e.g., Hall, 1988). What is most distinctive about this rethinking of the failure of the American Left-and Apple is representative of an important tendency here -is twofold: First, the acknowledgment that a democratic rights-based discourse is not simply or necessarily a liberal facade; and second, the return to common sense and culture-to phenomenological questions. The crisis of historical materialism-reflected intellectually in the failure of both economism and structuralism, and politically in the decline of Eurocommunism and the collapse of East Bloc Soviet Marxism--has culminated in a post-Marxist discourse which has necessarily precipitated a new dialogue between the political left and the phenomenological tradition. ${ }^{1}$

Strictly speaking, there is, of course, nothing new in this. From its birth phenomenology has had an ambivalent and changing relation to politics, power, and social movements. Phenomenological, existential, and hermeneutic theories have, in particular historical contexts, lent themselves as intellectual resources for the full political spectrum, from right to left (however misleading such terms may increasingly be). What is most striking, however, is that though the current crisis of historical materialism has engendered diverse responses, the most penetrating 
versions share a return to lived experience, as well as to the problematics of language and culture.

Three broad theoretical currents can be seen as defining the most influential responses in advanced capitalism to the crisis of Marxism: the critical theory associated with Habermas' theory of communicative action and related approaches; the neoGramscian turn in cultural studies (a perspective which underlies Apple's article); and the various poststructuralist efforts (from Foucault to Derrida) to escape the essentialisms and logocentrism which underlie all social and political theory. Each of these currents reflects a specific confrontation with phenomenological issues: for Habermas, the Lebenswelt is reconceptualized as a site of colonization by power and money; for neo-Gramscian theorists, how common sense and popular culture have become subverted as part of the formation of a conservative hegemonic bloc emerges as the central theme; and for poststructuralism in its various guises, the presuppositions of reading, writing, subjectivity, power, and meaning constitution are all called into question (see Morrow, 1990).

The interview is a mode of intellectual production which has come to play an increasingly important role in the communication and popularization of social theory (e.g., Shor \& Freire, 1987). What is at issue here is not the role of the interview in the sense of a media pseudo-event or even the hagiography of recording the spoken word of les grands penseurs. Rather, what is brought into view is the heuristic and pedagogic function of the interview as dialogue, a narrative form which allows ideas in all their contradictoriness and convoluted relation to lived experience to come alive. What is lost in linear elegance is compensated for through seeing the formation of social theory and practices as part of an ongoing process of argumentation and self-reflection.

The interview also connects personal history and intellectual biography in a way that provides an important antidote to "banking" theories of education, as well as suggesting important questions about the formation and functions of critical intellectuals. On the one hand, Apple resembles Gramsci as one of the rare major radical intellectuals with underprivileged, nonmiddle-class backgrounds. On the other, the paradox of the contemporary intellectual, irrespective of social origin, is the academization of intellectual discourse. ${ }^{2}$ Clearly, Apple resists this process, but even for him the academy remains the primary bastion of autonomy against the processes of conservative restoration against which he writes. 
The interview also implicitly poses important questions in the sociology of knowledge about the conditions under which those links between personal biography and reflections on power are made or not made, and how. Apple represents the classic situation of linking the personal experience of poverty to a critique of society-but this is not a case that can be easily generalized as the motivational foundation for critical theory. For every Michael Apple, there are many other radical intellectuals who, despite coming from more or less privileged backgrounds, have also become the men and women at the vanguard of voicing the concerns of the "other America." The complex formation of critical intellectuals is a process which, in turn, can only be understood in relation to the processes that have shaped the formation of a neoconservative intellectual elite in the United States.

As Apple suggests in both his article and interview, the populist conservative restoration in the United States is nevertheless inherently unstable and contradictory. Growing social problems, as well as internal divisions in the dominant coalition, will eventually bring back to the political agenda demands for radical educational reform. Above all, the persistence of old and the emergence of new forms of poverty resulting from the unleashing of market forces will eventually challenge the democratic pretensions of the New Right. That these burdens fall unequally on minority groups and women will open up new possibilities for a populist democratic coalition of those disillusioned by the false promises of the state. ${ }^{3}$

The lessons of Britain and the United States provide a sober warning for countries such as Canada where progressive conservative restoration has thus far been primarily at the level of the policies of the current political regime, rather than penetrating more deeply into civil society in the form of a right-wing populist hegemony. Further, these two extreme cases should also call into question many assumptions about the transformative potential of new social movements whose progressive character cannot be taken for granted.

The work of Apple is representative, in short, of a body of work whose suggestiveness for new forms of critical phenomenology in education cries out for empirical investigation and theoretical dialogue. ${ }^{4}$

\section{Notes}

1. A strong and influential formulation of such a post-Marxist tendency informed by poststructuralism can be found in Laclau and Mouffe (1985); for critiques of American education influenced by 
these and related tendencies, see Aronowitz and Giroux (1985), Wexler (1987), and Giroux (1988).

2. A pessimistic interpretation of this process is developed by Jacoby (1987); for a more optimistic rejoinder, see Birnbaum (1988).

3. For a provocative and prophetic prefiguration of such possibilities, see West (1988), as well as Bowles and Gintis (1986) and Birnbaum (1988).

4. As an example of such theoretical debate, see the comparison of the work of Apple and Henry Giroux in Torres and Morrow (1990).

\section{References}

Aronowitz, S., \& Giroux, H.A. (1985). Education under siege: The conservative, liberal and radical debate over schooling. South Hadley, MA: Bergin \& Garvey.

Birnbaum, N. (1988). The radical renewal: The politics of ideas in modern America. New York: Pantheon.

Bowles, S., \& Gintis, S. (1986). Democracy and capitalism: Property, community and the contradictions of modern social thought. New York: Basic Books.

Giroux, H.A. (1988). Schooling and the struggle for public life: Critical pedagogy in the modern age. Minneapolis: University of Minnesota Press.

Hall, S. (1988). The toad in the garden: Thatcherism among the theorists. In L. Grossberg \& C. Nelson (Eds.), Marxism and the interpretation of culture (pp. 35-57). Urbana and Chicago: University of Illinois Press.

Jacoby, R. (1987). The last intellectuals: American culture in the age of academe. New York: Basic Books.

Laclau, E.C., \& Mouffe, C. (1985). Hegemony and socialist strategy: Towards a radical lemocratic politics. London: Verso.

Morrow, R.A. (1990). Critical theory, Gramsci, and cultural studies: From structuralism to poststructuralism. In P. Wexler (Ed.), Critical theory now. New York, Philadelphia, and London:

Falmer Press.

Shor, I., \& Freire, P. (1987). A pedagogy of liberation: Dialogues on transforming education. South Hadley, MA: Bergin \& Garvey.

Torres, C.A., \& Morrow, R.A. (1990, July). Theories of hegemony and legitimation: The implications for education in the work of Apple and Giroux. Paper prepared for the XII World Congress of Sociology, Sociology of Education Section, Madrid.

West, C. (1988). Marxist theory and the specificity of Afro-American oppression. In L. Grossberg \& C. Nelson (Eds.), Marxism and the interpretation of culture (pp. 17-29). Urbana and Chicago: University of Illinois Press.

Wexler, P. (1987). Social analysis of education: After the new sociology. London and New York: Routledge \& Kegan Paul. 